\title{
Mobile coronary care
}

\author{
M. J. Walsh, G. Shivalingappa, K. Scaria, C. Morrison, B. Kumar, \\ C. Farnan, N. C. Chaturvedi, D. McC. Boyle, and J. M. Barber \\ From the Cardiac Department, The Ulster Hospital, Dundonald, Belfast, N. Ireland
}

We present our experience with a mobile coronary care unit which is effective and inexpensive. Of the 50I patients seen in the first year, we analysed the first 300 and compared them with III patients admitted by conventional means. We have used a coronary prognostic index to compare the two groups. The hospital mortality for those seen by the unit was 9 per cent and for conventional admissions 22 per cent. The lower mortality for mobile coronary care unit patients was reflected in all age groups. The staffing and financial aspects are discussed. The approximate cost per call was $£ 2 \cdot 20$. It is concluded that mobile coronary care units have an important part to play in the reduction of the mortality from acute myocardial infarction.

The need for hospital coronary care units in the management of acute myocardial infarction has been widely accepted. Mobile coronary care units have been considered wasteful in terms of finance and skilled personnel (Oliver, Julian, and Donald, 1967; Lown and Ruberman, 1970; Sidel, Acton, and Lown, 1969; Shillingford, 197I). We do not agree, and describe our experience of an inexpensive and effective method.

\section{Method}

The Ulster Hospital coronary care unit serves the needs of East Belfast and part of North Down, with a total population of approximately 250,000 . As described previously (Barber et al., 1970), coronary care is brought to the patient with the minimum of delay by using the staff of the coronary care unit and the ordinary ambulance service. We have compared the results of patients managed by the mobile coronary care unit with patients admitted to the unit by conventional methods. Myocardial infarction was considered to be present if at least two of the following criteria were satisfied. (I) Characteristic clinical presentation; (2) $Q$ waves, ST elevation, or $T$ inversion in the electrocardiograph with evolutionary changes; (3) raised serum enzymes. Patients were said to have had an ischaemic episode if they had cardiac pain but neither of the other criteria.

We constructed the coronary prognostic index as described by Norris et al. (I969) for the patients in each group. The index could not be calculated for one patient seen by the mobile coronary care unit.

We have where possible adopted an early discharge policy. Patients with myocardial infarction

Received I3 September I97I. were discharged by the tenth day provided there was no clinical or social reason to the contrary. Patients with shock, cardiac failure, recurrent chest pain, recurrent arrhythmias, or thromboembolic phenomena were kept as long as necessary.

A community-care sister attached to the coronary care unit saw the patients in hospital and, in co-operation with their family physician, visited them at home soon after discharge. Patients were reviewed three months after their attack.

Where applicable, $\chi^{2}$ testing for significance was calculated.

\section{Results}

We present data for the first 300 patients dealt with by the mobile coronary care unit and for 112 patients admitted by conventional means over approximately the same period.

Of the patients seen by the mobile coronary care unit, 50 per cent had acute myocardial infarction, 24 per cent had ischaemic episodes, 5 per cent were dead on arrival of the team, while in 21 per cent other diagnoses were made. Of the latter, a number had acute left ventricular failure or arrhythmias. Of patients admitted conventionally to the coronary care unit, 69 per cent had acute myocardial infarction and 31 per cent had ischaemic episodes.

Table I shows the various delay factors. Eighteen per cent of the patients seen by the mobile coronary care unit were under intensive care within one hour of the onset of symptoms, 39 per cent were seen within two hours, and 72 per cent within six hours.

The number of days spent in hospital by patients with acute myocardial infarction is 
TABLE I Delay factors and route of admission

\begin{tabular}{lll}
\hline Median delay times & Mobile & Conventional \\
\hline Total delay time & $3 \mathrm{hr}$ & $5 \mathrm{hr} 40 \mathrm{~min}$ \\
Patient delay time & $\mathrm{I} \mathrm{hr} 50 \mathrm{~min}$ & $4 \mathrm{hr}$ \\
Doctor delay time & $45 \mathrm{~min}$ & Residual time \\
Mobile unit time & $13 \mathrm{~min}$ & $=2 \mathrm{hr}$ \\
\hline
\end{tabular}

Definitions:

Total delay time $=$ Time from onset of symptoms to intensive care conditions whether in hospital or outside

Patient delay time $=$ Time from onset of symptoms to the patient's call for help

Doctor delay time $=$ Time taken by the doctor to summon the mobile unit after he has been contacted

Mobile unit time $=$ Time take by mobile unit to reach patient after receipt of call

Residual time = Time from patient's call for help to intensive care conditions by conventional methods

shown in Table 2. Patients admitted by the mobile coronary care unit had a shorter time in hospital $(P<0.00 \mathrm{r})$. Fifty per cent of the deaths occurred within 24 hours of admission and 73 per cent within 72 hours. Of the patients admitted by the mobile coronary care unit, 67 per cent were men and of conventional admissions 60 per cent were men. Tables 3 and 4 relate age and coronary prognostic index to route of admission. In neither case was there a significant difference. The overall hospital mortality for the coronary care unit was 14 per cent and at three months I8 per cent had died. An analysis of hospital and three-month mortality related to age and coronary prognostic index is given in Tables 5 and 6.

\section{Cost and staffing}

Junior medical staff of the coronary care unit, mobile coronary care unit, and general medical wards was 2 registrars, 3 senior house officers, and 2 pre-registration house officers. Some night cover was provided by a senior house officer in geriatric medicine. Two staff nurses are on duty in the coronary care unit

TABLE 2 Number of days spent in hospital of patients with myocardial infarction

\begin{tabular}{lll}
\hline & $\begin{array}{l}\text { Io days } \\
\text { or less }\end{array}$ & $\begin{array}{l}\text { More than } \\
\text { IO days }\end{array}$ \\
\hline Mobile admissions & 106 & 44 \\
Conventional admissions & 37 & 40 \\
\hline
\end{tabular}

TABLE 3 Age and route of admission

\begin{tabular}{llcr}
\hline & Mobile & Conventional & Total \\
\hline 50 years or less & $25(17 \%)$ & $9(12 \%)$ & 34 \\
$51-70$ years & $88(59 \%)$ & $40(52 \%)$ & 128 \\
over 70 years & $37(25 \%)$ & $28(36 \%)$ & 65 \\
& 150 & 77 & 227 \\
\hline
\end{tabular}

at all times and one accompanies the doctor on mobile coronary care unit calls.

In the first year, the team spent 480 hours 49 minutes outside hospital, on average I hour 20 minutes per day. Seventy-five per cent of the calls were between 8.0 a.m. and 8.0 p.m. The capital cost of setting up the mobile coronary care unit was $£ 1800$. Allowing for maintenance and depreciation of van and equipment, the running costs for the first year, including the ambulance journey, amounted to approximately $£$ I100 or $£ 2.20$ per call.

\section{Discussion}

The principal aim of mobile coronary care is to reduce the interval between onset of symptoms and intensive care and to prevent or correct serious arrhythmias. Not only is the interval reduced but the patient's condition at home is assessed and stabilized before transport. Intensive surveillance is maintained in transit from home to the coronary care unit, a time of high risk. Pantridge (1970) has shown that this technique can effectively reduce hospital mortality from about 20 per cent to 12 per cent, and only mobile coronary care is able to lower community mortality from acute myocardial infarction significantly.

While the aim of the mobile coronary care unit at the Ulster Hospital is the same as at other units, the technique employed is different and we have set out to show that the clinical results obtained are comparable to the more expensive mobile coronary care units.

The fact that most of the deaths and major complications from acute myocardial infarction occur in the early days, combined with

TABLE 4 Coronary prognostic index related to route of admission

\begin{tabular}{lll}
\hline $\begin{array}{l}\text { Coronary prog- } \\
\text { nostic index }\end{array}$ & $\begin{array}{l}\text { No. of mobile } \\
\text { admissions }\end{array}$ & $\begin{array}{l}\text { No. of conven- } \\
\text { tional admissions }\end{array}$ \\
\hline$<4$ & $28(19 \%)$ & $13(17 \%)$ \\
$4-5$ & $48(32 \%)$ & $18(23 \%)$ \\
$6-7$ & $38(26 \%)$ & $20(26 \%)$ \\
$8-9$ & $22(15 \%)$ & $16(20 \%)$ \\
$10+$ & $13(8 \%)$ & $10(13 \%)$ \\
\hline
\end{tabular}


the extreme pressure on the cardiac beds, led us to introduce an early discharge policy. Of the patients with myocardial infarction, 50 per cent were discharged home by the tenth day and this was a faster discharge rate than in any previously reported series. An unexpected finding was that patients handled by the mobile coronary care unit had a shorter stay. This enabled much more efficient use of available beds. Our experience suggests that the policy was justified.

In Belfast in 1965 the time interval from onset of coronary attack and admission to hospital ward was approximately 8 hours (McNeilly and Pemberton, 1968). Our median total delay time was 3 hours for patients seen by the mobile coronary care unit, and this was 2 hours 40 minutes less than that of patients admitted conventionally. Similar delay times have been reported from other mobile coronary care units (Pantridge and Geddes, 1967; Kernohan and McGucken, 1968; Robinson and McLean, 1970). The biggest single factor was patient delay time. A reduction in this will require community education (Yu et al., 197I).

The majority of patients seen by the mobile coronary care unit had acute ischaemic heart disease and 50 per cent had myocardial infarction. Our experience, which now includes 670 calls, revealed that only some I per cent were unjustified. Other mobile coronary care units have reported that the service was seldom abused (Robinson and McLean, 1970). Table 3 reflects our policy of not having any upper age limit for admission. In this we differ from some other units. The patients admitted conventionally were slightly older, but this difference was not significant.

Comparison of results from different units is made difficult by the fact that severity of the infarction may vary considerably. Norris et al. (1969) have suggested that their coronary prognostic index provides an unbiased method for the assessment of new forms of treatment for myocardial infarction. We have used this index to compare our two groups. As can be seen from Table 4, the indices in both groups were comparable. Our figures show that patients seen by the mobile coronary care unit have a significantly lower mortality both in hospital $(\mathrm{P}<0.01)$ and at three months $(P<0.001)$, and this trend was present in each prognostic group (Table 5). The mortality of those admitted by conventional methods was similar to that described by Norris et al. (I969). From Table 6 it will be seen that the mortality $(8 \%)$ for patients under 70 seen by the mobile coronary care unit is similar to that described by Pantridge (1970) for pa-
TABLE 5 Mortality related to coronary prognostic index (patients with acute myocardial infarction)

\begin{tabular}{|c|c|c|c|c|c|c|}
\hline \multirow{2}{*}{$\begin{array}{l}\text { Coronary } \\
\text { prognostic } \\
\text { index }\end{array}$} & \multicolumn{3}{|c|}{ Mobile admissions } & \multicolumn{3}{|c|}{ Conventional admissions } \\
\hline & $\begin{array}{l}\text { No. of } \\
\text { patients }\end{array}$ & $\begin{array}{l}\text { Hospital } \\
\text { mortality }\end{array}$ & $\begin{array}{l}\text { Three-month } \\
\text { mortality }\end{array}$ & $\begin{array}{l}\text { No. of } \\
\text { patients }\end{array}$ & $\begin{array}{l}\text { Hospital } \\
\text { mortality }\end{array}$ & $\begin{array}{l}\text { Three-month } \\
\text { mortality }\end{array}$ \\
\hline $\begin{array}{l}<4 \\
4-5 \\
6-7 \\
8-9 \\
10+\end{array}$ & $\begin{array}{l}28 \\
48 \\
38 \\
22 \\
13\end{array}$ & $\begin{array}{r}0 \% \\
6 \% \\
11 \% \\
14 \% \\
23 \%\end{array}$ & $\begin{array}{r}0 \% \\
8 \% \\
16 \% \\
18 \% \\
30 \%\end{array}$ & $\begin{array}{l}13 \\
18 \\
20 \\
16 \\
11\end{array}$ & $\begin{array}{r}0 \% \\
11 \% \\
25 \% \\
31 \% \\
55 \%\end{array}$ & $\begin{array}{r}0 \% \\
17 \% \\
35 \% \\
38 \% \\
73 \%\end{array}$ \\
\hline
\end{tabular}

tients seen within one hour of the onset of symptoms. The trend for lower mortality rate in patients seen by the mobile coronary care unit is also present in patients over 70 . We feel these results indicate that our mobile coronary care unit is as effective as others.

It has been suggested (Oliver et al., I967; Lown and Ruberman, 1970; Sidel et al., 1969; Shillingford, 197I) that mobile coronary care units are unduly expensive and wasteful of medical manpower. In the Ulster Hospital the junior medical staff is shared between the general medical wards and the coronary care unit. We believe that the number mentioned represents the minimum requirement for such departments of an area hospital. Because of this pooling of resources, the provision of our mobile coronary care unit has not required any additional medical staff. Also, we have not found it necessary to provide additional nurses. Since the van was driven by a doctor and an ordinary ambulance was then converted temporarily into a cardiac ambulance, it was not necessary to employ additional ambulance drivers. The major portion of the running cost of most mobile coronary care units is the salary of extra medical, nursing, and ambulance staff.

The time that the doctor and nurse are outside hospital on mobile duties averaged $\mathrm{I}$ hour 20 minutes a day and this occurred mostly during normal working hours. This has not imposed an undue strain on the second on call. We consider that taking an active part in

TABLE 6 Mortality related to age (patients with acute myocardial infarction)

\begin{tabular}{|c|c|c|c|c|c|c|}
\hline \multirow[t]{2}{*}{ Age (yr) } & \multicolumn{3}{|c|}{ Mobile admissions } & \multicolumn{3}{|c|}{ Conventional admissions } \\
\hline & $\begin{array}{l}\text { No. of } \\
\text { patients }\end{array}$ & $\begin{array}{l}\text { Hospital } \\
\text { mortality }\end{array}$ & $\begin{array}{l}\text { Three-month } \\
\text { mortality }\end{array}$ & $\begin{array}{l}\text { No. of } \\
\text { patients }\end{array}$ & $\begin{array}{l}\text { Hospital } \\
\text { mortality }\end{array}$ & $\begin{array}{l}\text { Three-month } \\
\text { mortality }\end{array}$ \\
\hline $\begin{array}{l}70 \text { or less } \\
>70 \\
\text { All ages }\end{array}$ & $\begin{array}{r}111 \\
39 \\
150\end{array}$ & $\begin{array}{r}8 \% \\
13 \% \\
9 \%\end{array}$ & $\begin{array}{l}12 \% \\
15 \% \\
13 \%\end{array}$ & $\begin{array}{l}49 \\
28 \\
77\end{array}$ & $\begin{array}{l}18 \% \\
29 \% \\
22 \%\end{array}$ & $\begin{array}{l}24 \% \\
36 \% \\
30 \%\end{array}$ \\
\hline
\end{tabular}


the management of patients with acute myocardial infarction is an essential part of postgraduate training for young doctors.

Since a mobile coronary care unit can be run effectively from an area hospital without extra staff and with minimal capital and running expenses we feel that coronary care units should provide such a service. In this way a significant reduction can be made on the appalling mortality from acute myocardial infarction.

Our thanks are due to Sisters Helen Kerr, Margaret Gass, and Aileen Carroll with their nursing team, the staff of the Northern Ireland Hospitals Authority Ambulance Service for their invariable co-operation, Mrs. Joan Crawford for the clerical work, and to the Holywood Round Table for the gift of the van.

\section{References}

Barber, J. M., Boyle, D. McC., Chaturvedi, N. C., Gamble, J., Groves, D. H. M., Millar, D. S., Shivalingappa, G., Walsh, M. J., and Wilson, H. K. (1970). Mobile coronary care. Lancet, 2, 133.

Kernohan, R. J., and McGucken, R. B. (1968). Mobile intensive care in myocardial infarction. British Medical fournal, 3, 178 .

Lown, B., and Ruberman, W. (1970). The concept of precoronary care. Modern Concepts of Cardiovascular Disease, 39, 97.

McNeilly, R. H., and Pemberton, J. (1968). Duration of last attack in 998 fatal cases of coronary artery disease and its relation to possible cardiac resuscitation. British Medical fournal, 3, 139.

Norris, R. M., Brandt, P. W. T., Caughey, D. E., Lee, A. J., and Scott, P. J. (1969). A new coronary prognostic index. Lancet, $\mathbf{I}, 274$.

Oliver, M. F., Julian, D. G., and Donald, K. W. (1967). Problems in evaluating coronary care units. American fournal of Cardiology, 20, 465.

Pantridge, J. F. (1970). Mobile coronary care. In Modern British Cardiac Care, p. 318. (Suppl. to Hospital Management, July/August 1970, on the occasion of the VI World Congress of Cardiology, London.) Sponsored by and compiled in cooperation with the King's Fund Hospital Centre and the British Hospital's Export Council. Whitehall Press.

Pantridge, J. F., and Geddes, J. S. (1967). A mobile intensive-care unit in the management of myocardial infarction. Lancet, 2, $27 \mathrm{I}$.

Robinson, J. S., and McLean, A. C. J. (1970). Mobile coronary care. Medical fournal of Australia, 2, 439.

Shillingford, J. P. (197I). The management of acute myocardial infarction. Postgraduate Medical fournal, 47, 23.

Sidel, V. W., Acton, J., and Lown, B. (1969). Models for the evaluation of pre-hospital coronary care. American fournal of Cardiology, 24, 674.

Yu, P. N., Bielski, M. T., Edwards, A., Friedberg, C. K., Grace, W. J., January, L. E., Likoff, W., Scherlis, L., and Weissler, A. M. (I97I). Intersociety commission report for heart disease resources: resources for the optimal care of patients with acute myocardial infarction. Circulation, 43, (May) Ar7r.

Requests for reprints to Dr. M. J. Walsh, Cardiac Department, The Ulster Hospital, Dundonald, Belfast, N. Ireland. 